\title{
A controversial idea as a cultural resource: The Lysenko controversy and discussions of genetics as a 'democratic' science in postwar Japan
}

Social Studies of Science 2015, Vol. 45(4) 546-569 (C) The Author(s) 2015

Reprints and permissions: sagepub.co.uk/journalsPermissions.nav DOI: 10.1 I77/03063।27/5596460

sss.sagepub.com

@SAGE

\section{Kaori lida}

Department of Evolutionary Studies of Biosystems, SOKENDAI (The Graduate University for Advanced Studies), Hayama, Japan

\begin{abstract}
The Japanese discussion of the theory of Soviet agronomist Trofim D. Lysenko began in the postwar years under the American occupation. Leftists introduced Lysenko's theory immediately after the war as part of a postwar scientists' movement. Unlike many American geneticists, who sharply criticized the theory, Japanese geneticists initially participated in the discussion in an evenhanded way; their scientific interests in the roles of cytoplasm and the environment in heredity shaped their initial sympathetic reaction. As the Cold War divide deepened, however, Japanese scientists began expressing sharp anti-Lysenko criticisms that resembled the American criticisms. Interestingly, throughout the period, Japanese geneticists' overall aim in the discussion remained largely unchanged: to effectively reconstruct their discipline and maintain its proper image and authority. However, the shift in their reaction occurred due to an evolving sociopolitical context, especially the shift in the meaning of 'democratic' science from a science that employed democratic processes to a science of a liberal-democratic state. Regarding Lysenko's idea as a cultural resource could help to explain how and why it was treated differently in different places, and why a controversy emerged in certain contexts but not in others.
\end{abstract}

\section{Keywords}

Cold War, controversy, cultural resource, democracy, genetics, Japan, Lysenkoism

\section{Corresponding author:}

Kaori lida, Department of Evolutionary Studies of Biosystems, SOKENDAI (The Graduate University for Advanced Studies), Hayama, Miura-gun, Kanagawa 240-0193, Japan.

Email: iida_kaori@soken.ac.jp 


\section{Introduction}

Scientific controversies offer valuable sites for social scientists and historians to analyze social processes of knowledge production that are otherwise largely invisible to observers outside of laboratories (e.g. Martin and Richards, 1995; Sismondo, 2010: 120-135). However, scientists may have numerous motivations to become involved in a controversy, and in certain cases their aims may not be directly related to the production of scientific knowledge. In this article, I analyze a historical process in which scientists' responses to a controversial idea changed significantly due to a shift in the sociopolitical context rather than a change in their scientific understanding. In this study, I regard the controversial idea as a cultural resource that participants can use to accomplish various goals, which may not involve defending either side of the scientific debate generated by the idea. This analytical lens helps to determine how and why a certain idea or belief is treated differently in different times and places and becomes a controversy in some contexts but not in others.

I analyze a case in postwar Japan from the late 1940s to the mid-1950s: the evolving discussions of a set of ideas proposed by the Soviet agronomist Trofim D. Lysenko (1898-1976). Lysenko developed a theory of heredity based on the concept of the inheritance of acquired characteristics, which had been controversial since the late 1930s both scientifically and politically. After the Second World War, geneticists in the United States sharply criticized his theory as pseudoscientific; in contrast, the initial reactions of Japanese geneticists, most of whom were not Marxists, were quite different. In the immediate postwar years in Japan, Lysenko's ideas were discussed sympathetically by those who generally regarded his complete negation of Mendelism to be scientifically incorrect but were interested in the implications of Lysenko's claims, such as implications about the role the environment plays in genetic problems. In this article, I term this type of discussion 'sympathetic'; in other words, 'sympathetic' in this context does not mean supportive. Around 1950, in the context of the Cold War, Japanese geneticists' reactions came to resemble the sharp criticisms of many of their American counterparts. Interestingly, throughout the period, the overall aim of Japanese geneticists in this discussion remained largely unchanged: to effectively reconstruct their discipline and maintain its proper image and authority. During the earlier phase of the discussion, Japanese geneticists' approach to achieving their aim was to adopt a sympathetic position, but around 1950 they became sharply critical. The shift occurred due to the evolving sociopolitical context.

The history of Lysenkoism has most often been told as a story of the Soviet Union and the Cold War (see, for example, Graham, 1987; Joravsky, 1970; Krementsov, 1997; RollHansen, 2005). In recent years, however, there have been further studies of Lysenko controversies outside the Soviet Union that focus on local issues rather than international relations during the Cold War (see, for example, Cassata, 2012; DeJong-Lambert, 2009, 2012; Gordin, 2012; Harman, 2003; Schneider, 2003, 2012; Selya, 2012; Wolfe, 2010, 2012). Based on recent studies, DeJong-Lambert and Krementsov (2012) call the Lysenko controversy a 'global phenomenon'. In summarizing this controversy, which spanned wide geographical areas, they suggest that various actors, who had a multitude of motives and goals, deployed the controversy 'as a particular cultural resource' to 
address a variety of issues (DeJong-Lambert and Krementsov, 2012: 380). The controversy could serve as a resource in pursuing the development of a consensus on scientific themes, in debating the relationship between science and society, or in shaping the public image of genetics and of science in general. This study of Japan contributes to a comparative literature in which studies of countries outside the Soviet Union, the United States, and Europe remain relatively scarce. Further studies of Lysenko cases in different countries, especially when employing the 'cultural resources' analytical perspective, would reveal complex social processes of the mobilization of knowledge.

Regarding Lysenkoism as a cultural resource helps the reappraisal of the narrative of the controversy in postwar Japan. A book published by Teiri Nakamura (1932-2014) in Japanese in 1967 (reprinted in Nakamura, 1997 [1967]) significantly affected the Japanese historiography of postwar discussions of Lysenko's theory. To date, it is the only detailed historical account to describe both the sympathetic and the critical phases of the Japanese discussion. Nakamura majored in biology in college and participated as a Marxist in discussions of Lysenko's biology in his 20s (in the 1950s to early 1960s). The book reads as a self-reflexive examination of these discussions to identify why the discussions eventually 'failed' in his view. Nakamura (1997 [1967]) viewed the initial sympathetic discussion as 'wholesome' because it focused on science rather than politics, but the 'wholesome' discussion eventually failed because of a 'politicization' of science (p. 67). This historiography was deeply influenced by the author's relationship to the controversy. In this article, I argue that both the sympathetic and critical reactions reflected a dynamic, complex interaction between scientific and sociopolitical interests.

In the following, I illustrate how participants in the discussion actively used Lysenko's ideas to accomplish their own goals, which reflected their evolving sociopolitical needs. In the immediate postwar years, the social context of postwar reconstruction played a critical role in shaping the sympathetic discussion. For leftists, who introduced Lysenko's ideas after Japan's defeat, the discussion supported a democratization movement that sought to reform both science and society. For younger geneticists who facilitated discussions of Lysenko's ideas, the goal was to practice their idea of democracy in the new society and to create a model for democratic science. The purpose of the discussion for the more established geneticists of the older generation was to advance their theoretical preferences for physiological genetics and to explore a unique and competitive direction of genetic research as well as to shape an appropriately democratic image of their discipline in the new era. It was perceived as unwise to sharply criticize Lysenko's idea because criticism might create the appearance of establishing another 'orthodoxy' and thus of contradicting the democratic movement. To effectively reconstruct their discipline, Japanese geneticists continued to emphasize a certain aspect of Lysenko's ideas, such as the role of environment in genetic problems, that allowed them to continue forward-looking discussions.

Their sympathetic responses waned, however, as the Cold War took hold in the 1950s and sharper criticisms of Lysenkoism appeared in Japan. The understanding of 'democratic' shifted drastically from fundamental democratic processes, such as open discussions, to the values of a liberal-democratic state. Geneticists came under some pressure to react to Lysenkoism to protect their research interests and careers, as well as the discipline itself. Attention to factors other than nucleic genes (such as the role of environment 
and cytoplasm), which had long been of interest in Japan, were likely to be associated with Lysenkoism and communism. Public expressions of critical reactions came to be a more appropriate tactic to effectively reconstruct their discipline.

Finally, this study demonstrates how postwar American power affected other countries and the strategies adopted by scientists in those other countries. As John Krige (2008) argues in the case of Europe, the postwar economic, military, scientific, and technological asymmetries between the United States and an impoverished Europe allowed the United States 'to shape the research agendas, the institutions, and the allegiances of scientists in Western Europe in line with US scientific, political, and ideological interests in the region' (p. 3). While Krige (2008) focuses primarily on Europe and does not deal with East Asia, his argument is highly valuable for analyzing the postwar reconstruction of Japan because the country was exposed to an immensely asymmetrical power relation under the US occupation. In this article, I illustrate how American power in the Cold War context affected the course of discussions of Lysenkoism in Japan in the 1950s and the role played by Japanese geneticists. I suggest that Japanese geneticists employed their sharper criticisms as a strategy to reconnect their community with and gain recognition and authority in the international community.

\section{Science and democracy after the defeat: the postwar scientists' movement in Japan}

After arriving in Japan, the Americans began an ambitious experiment to demilitarize and democratize Japan under the Supreme Commander for the Allied Powers (SCAP). With a series of SCAP directives issued under that agenda, left-wing movements revived and grew dramatically. In 1925, the Japanese government had enacted the Peace Preservation Law to suppress anti-government activities, including communism, socialism, and anarchism. Consequently, nearly 80,000 people were arrested between 1925 and 1945 (Ohara Institute for Social Research of Hosei University (OISRHU), 1965), and left-wing activities in Japan were almost completely crushed. The activists were often threatened and tortured and consequently many accepted tenkō ('ideological reverse', which was a condition for release). When the SCAP abolished the Peace Preservation Law in October 1945 and released wartime 'thought criminals' from prisons, including top leaders of the Japanese Communist Party, the released activists (who refused tenkō) gained enormous respect and substantial influence among Japanese intellectuals. In contrast to those activists, most intellectuals survived because they did not engage in anti-government activities and also did not directly fall victim in battle. Postwar thought in Japan was deeply rooted in these wartime experiences and bitter emotions of remorse and self-criticism. For Japanese intellectuals, Marxism was particularly attractive because the concept appeared to offer a theoretical framework to understand and overcome the bitter past (Dower, 1999: 233-239; Oguma, 2002: 175-186).

In January 1946, approximately 200 scholars in the natural and social sciences established the Association of Democratic Scientists, or Minka (Minshushugi kagakusha $k y \bar{k} k a i$ ), as the 'united front for scientific activities' (e.g. Nakayama, 2001). One of the founding members of Minka wrote that scientists were responsible for producing 
scientific results that could contribute to the improvement of welfare and the 'rational progress of the world' (cited in Tsuge, 1980: 51-52). The scientists' movement in postwar Japan bore numerous similarities to the British left-wing scientists' movement in the 1930s. With the Great Depression and the use of new weapons in warfare, British scientists became concerned with the relationship between science and society, and a Marxist view of science spread rapidly among younger scientists (McGucken, 1984: 71-94; Paul, 1983). The leading advocate among these individuals was the British physicist John Desmond Bernal. The general views of science expressed by Bernal, such as criticisms of war and fascism, the reconsideration of scientific aims and organizations, and hope for change, attracted younger scientists in Japan after the defeat.

In 1946, Minka members initiated the democratization of kyōshitsu (departments) and kōza (laboratories) at universities, a reform inspired by Bernal's influential book, published in 1939, The Social Function of Science (Bernal, 1939; Hiroshige, 1960: 41-43). Shōichi Sakata (1911-1970), a prominent physicist and Marxist, was impressed by the book and began the reform of laboratories as the first step in the larger reorganization of science and society that Bernal had advocated. The reform involved the removal of the 'dictatorship' of the professor within the laboratory, which was, according to Sakata (1947), the cause of all 'feudalistic harms', including the hierarchical relationships among members and the closed environment of each laboratory (p. 10). Through the reform, each research member of a laboratory had the right to be involved in the management of their laboratory, such as the recruitment of new members, the election of the director of their lab, and the allocation of the research budget.

Democratization movements in postwar Japan were inspired by Marxism, but the actual reforms and discussions that took place in Japan often concerned fundamental issues. For many, democratization did not require abstract theories. Indeed, democracy often implied a state in which everyone would think independently and have an equal chance to speak. Whereas Minka's board members were mostly Marxists and included top members of the Communist Party, regular members were not necessarily Marxists or Communists, and the Association was not bound to a certain political party. As a democratizing organization, Minka attracted many younger scientists and students and reached a peak of more than 11,000 members in 1949 (Onuma et al., 1975: 25).

Leftists argued that the democratic process should produce better science to help create a better society. One aspect of the new science was that it was to be for the people. A preference for practical science was not perceived as an abstract ideal in the devastation of the immediate postwar years. In the case of genetics, Japanese leftists felt impatient with 'genetics in the ivory tower' and demanded actual agricultural production to relieve the severe food scarcity. Another aspect of the new science was the desire to not be influenced by trends in Western science. During the war, many Japanese intellectuals had expressed their perception that Japanese science was a mere 'imitation' of Western science and that it was necessary to create 'Japanese' science that was independent of the latter (see Morris-Suzuki, 1994: 144-145, 156-157). This concern only grew after the defeat. Leftists argued that Japan should create its own science by rethinking the foundations of the scientific method and philosophy, and by not merely following overseas trends and importing superficial ideas, which many believed that the Japanese had been doing since the Meiji era. In this social context, a few members of Minka introduced 
Lysenko's theory as part of the movement to reform science and society and to facilitate foundational discussions. Lysenko's ideas began to be discussed among many scholars regardless of their political positions, often in a sympathetic tone, although those who actively introduced his theory were attracted to the Soviet model of science. As I will demonstrate below, however, the social context significantly affected how Lysenko's theory was treated and discussed in postwar Japan.

\section{The development of Lysenkoism in the Soviet Union}

The name 'Lysenko' was not new to many agronomists and biologists in Japan at the time, particularly because of the method of 'vernalization', which involves the physiological manipulation of plants to induce faster development (e.g. Yamamoto, 1935). Lysenko claimed to have invented the method and reported that the pretreatment of winter grains at low temperatures would facilitate plant development. It was loudly advertised in Russia that this method significantly increased wheat harvests. By the mid-1930s, vernalization had become widely known (although in many countries, including Japan, it was not really a new method), and its potential applications in agronomy and plant physiology were being explored extensively (e.g. Roll-Hansen, 2005; Whyte, 1948).

In the Soviet Union, however, vernalization was not only a tool for botanical research but also a tool for political ascendancy. Under the Stalinist science system monopolized by the Central Committee of the Communist Party, Lysenko gained strong political support and began to take over agricultural institutions in the mid-1930s. Lysenko and his supporters claimed that there were the two competing types of biology, a 'socialist' biology and a 'bourgeois' biology, and that Lysenko was transforming socialist agriculture for the nation through socialist biology. Lysenko also used his vernalization work to construct a theory of heredity that was based on the concept of the inheritance of acquired characteristics, or the notion that characteristics acquired during an organism's lifetime could be passed to its offspring. He denied the existence of genes and chromosomes and was opposed to Mendelism, especially the form of Mendelian genetics promoted by Thomas H. Morgan (1866-1945) in the United States, which held that genes were real entities lined up on the chromosomes.

At the 1936 Lenin All-Union Academy of Agricultural Sciences meeting, opposing camps formed between followers of classical genetics and those of Lysenko's theory of heredity. Lysenko identified the prominent geneticist Nikolai Vavilov (1887-1943) as a major opponent. At the 1939 meeting, Lysenko and his supporters attacked Mendelism even more vociferously. News and rumors concerning political attacks on genetics in the Soviet Union circulated among geneticists outside the Soviet Union. Japanese geneticists learned of these developments, to some extent, through published articles in international journals and correspondence with geneticists abroad. However, Japan entered almost complete isolation by the end of 1941 (particularly with Germany's invasion of the Soviet Union and Japan's attack on Pearl Harbor), and the Japanese lost direct access to most information.

\section{Lysenko's theory as a resource for Japanese leftists}

After the end of the war, Lysenko's theory was introduced to Japan by leftists who regarded it as a bright symbol of new science. In 1946, Mitsuo Taketani (1911-2000), a 
Minka board member and Marxist physicist, applauded Lysenko as a 'brilliant scholar of agricultural technology' who had been 'carrying out a large undertaking' to 'connect science and the people' (reprinted in Taketani, 1969 [1946]: 121). Taketani believed that during wartime, technology in Japan had existed only for the benefit of the imperial government, which exploited workers under the worst conditions. Because the war had ended, he argued, 'we must get hold of technology in our hands' (Taketani, 1969 [1946]: 121). Such a system to link technology with the needs of the people appeared especially critical to democratize Japan, and Taketani found a suitable model in the Soviet Union. As had British Marxists before 1948 (Paul, 1983), Japanese leftists who introduced the theory were willing to ignore gloomy rumors concerning the USSR based on their belief that anti-Soviet reports must have been false. Instead, they attempted to see in Soviet biology what they hoped for, to facilitate the reform movement in Japan.

A Marxist Minka member who utilized Lysenko's theory quite effectively for the scientists' movement in postwar Japan was Ryūichi Yasugi (1911-1997). He majored in zoology at Tokyo Imperial University as an undergraduate student and was interested in dialectical materialism as an approach to biology. In the immediate postwar years, he was the only writer who read Lysenko's original writings in Russian, and thus his initial introduction of Lysenko's ideas became an important source of information in Japan. Yasugi published a detailed account of Lysenko's theory in 1947-1948. In the account, interestingly, he molded the image of Lysenko and his theory into what he thought Soviet biology should be. Yasugi (1968) later wrote that he had attempted to derive a 'rational interpretation' of what Lysenko had written; thus, there were 'some elements of Lysenko that [Yasugi] created' (p. 60).

Yasugi, who had studied biology and had a basic understanding of genetics, intentionally downplayed Lysenko's inaccurate claims regarding Mendelian genetics in order to attract non-Marxist biologists to discussions of his ideas. Yasugi's description differed substantially from Lysenko's actual claims and from the way most geneticists in the United States understood the theory at the time. According to Yasugi, a conflict between Lysenko's theory and Mendelian genetics should not entail their mutual negation. Lysenko was not insisting that Mendelian laws were absolutely inappropriate or that all of the facts recognized by Mendelian geneticists were incorrect. Yasugi (1948) reassured his colleagues that Lysenko also paid 'considerable respect' to Morgan's accomplishments (pp. 35-36). In any case, according to Yasugi (1948), it was 'dangerous to adhere to [Lysenko's] theory from A to Z' (p. 34). 'Only those who are ignorant about modern science and the history of science' would believe that a single person could produce a scientific theory in a complete form (Yasugi, 1948: 35). The issue for Yasugi was not to select either Mendelism or Lysenkoism but to rethink the foundation of genetics by using Lysenko's idea as the springboard.

Why should biologists rethink Mendelian genetics? According to Yasugi, one of the reasons for supporting Lysenko's theory was the strong connection between biology and agriculture in the Soviet Union. The lack of a practical aspect in the mainstream genetics led, in his view, to an inappropriate approach to genetic studies, namely, the separation of organisms from the environment. (It should be noted, however, that genetics in Japan had developed in close connection with agriculture (Iida, 2015; Onaga, 2015). Yasugi argued the connection was still insufficient.) Yasugi thought that if biology, including genetics, were well connected with agricultural practice, one would have to constantly 
consider the relationship between organisms and the environment. This was, according to Yasugi, precisely Lysenko's point. Lysenko was merely opposing the fundamental concept of contemporary genetics that separated organisms from the environment. Because of this problem, genetics deterministically explained all characteristics, including the developmental and evolutionary processes of organisms, by the function of genes (Yasugi, 1948: 30-31, 35). Through Yasugi's 'rational interpretation', Lysenko's complete negation of genes and chromosomes became a finer discussion of approaches to genetic and biological studies.

Finally, the introduction of Lysenko's ideas touched on concerns that were broadly shared by many Japanese intellectuals, such as the idea that genetics should contribute to agricultural production to relieve food scarcity, that Japanese science should not merely follow Western trends, and that science should be practiced, used, and managed democratically. For those who introduced Lysenko's ideas, his science was practical and contributed to the increase in food production in the Soviet Union. Moreover, it was an example of the pursuit of a direction independent of Western science and represented a democratic science closely connected to the people. Therefore, stimulating discussions of Lysenko's ideas was, for leftists, one way of initiating discussions on issues directly related to the postwar construction of Japan.

\section{Japanese geneticists: exploring their new genetics}

In the aftermath of the war, geneticists in the United States, concerned with political intrusions into science, dismissed Lysenko's ideas as pseudoscientific. In 1946, the fly geneticist Theodosius Dobzhansky (1900-1975) translated Lysenko's 1943 work Heredity and Its Variability into English (Lysenko, 1946). He decided to translate Lysenko's work to expose the content of the theory and make it available for critique (e.g. Gordin, 2012; Wolfe, 2010). Its publication was followed by a series of negative reviews expressing the view that Lysenko's work was not science and was more akin to a religious or political belief (e.g. Dunn, 1946; Glass, 1946). In contrast, Japanese geneticists' reactions were sympathetic in tone. It should be noted, however, that neither leftists such as Yasugi nor non-Marxist geneticists were supporting Lysenko's claim at this point. Just as leftists used some aspects of Lysenko's ideas to stimulate the democratization movement, geneticists also used the implications of his ideas as a resource to achieve their multiple goals.

The sympathetic discussion among geneticists was initiated and facilitated by the Neo-Mendel group formed by younger geneticists after the war (the name of the group implied a 'new' generation of geneticists and did not imply their theoretical preference regarding genetic theories). The group members published books and articles related to Lysenkoism, including several records of roundtable discussions. These publications reveal the younger geneticists' initial effort to democratize their field by encouraging open discussions of Lysenko's ideas. The way the geneticists of the older generation participated in the discussion was significantly influenced by these younger geneticists' expectations of a new democratic society.

Geneticists organized the first roundtable discussion on Lysenko's theory in March 1948. As the popularity of Lysenko's theory was increasing among leftists, geneticists 
were under pressure to examine the idea separately. Before the meeting, members of the Neo-Mendel group attempted to collect information on Lysenko's theory, especially the 1946 publication of Dobzhansky's translation of Lysenko's Heredity and Its Variability (Lysenko, 1946). Perhaps unsurprisingly, the group's members found that due to wartime isolation and the subsequent postwar occupation only one biologist in Japan had a copy of the work (Sato, 1948). Thus, writings by both Lysenko and anti-Lysenko critics were lacking.

Even before obtaining and circulating the single copy of Dobzhansky's translation, the first roundtable discussion on Lysenko's theory was hurriedly organized in March 1948 (Iden, 1948). Seven geneticists participated as discussants. Unfortunately, as one participant later recalled, the meeting was 'sluggish' (Sato, 1948: 12). Most, if not all, were aware of vernalization, but they had limited knowledge of Lysenko's theory of heredity and political developments. Some of them had read writings by Yasugi and a few others, and some had heard a gloomy rumor that Vavilov had died in prison or by execution or assassination. However, the participants felt that there was little information available to criticize Lysenko's theory because they had not read any of his original work.

The major source of new information at the meeting was a review of Dobzhansky's translation by the German-born American geneticist Richard Goldschmidt (1878-1958) (Goldschmidt, 1946). Yoshimaro Tanaka (1884-1972), a prominent silkworm geneticist who was also a central member in the major reform of the Genetics Society of Japan in 1920, was translating the review into Japanese at the time and introduced its content during the meeting. The review was highly negative in tone and stated, for example, that Lysenko developed 'very simple and primitive Lamarckism shrouded in pseudophysiological language' but 'with the argumentation of a shrewd lawyer' (Goldschmidt, 1946: 332-333). Goldschmidt, who had maintained a close connection with a community of Japanese biologists since the 1910s, sent a reprint directly to many Japanese geneticists to make them aware of the alarming Lysenko problem.

In contrast to Goldschmidt's concern, Tanaka was working on the translation in hopes of finding an explanation for the strange popularity of Lysenko's theory in Japan (Iden, 1948: 15). It was perplexing to Tanaka and other geneticists of the older generation; those who took an interest in Lysenko's theory were not only individuals who had no understanding of genetics but also younger geneticists who should have had extensive knowledge of the field. Tanaka noticed that those young researchers were thinking as if 'old genetics' had become a 'product of the past' and a 'new genetics' was rising. Tanaka asked, 'Where is this idea coming from?' (Iden, 1948: 15). Goldschmidt's review was not very useful for answering Tanaka's question.

It appears that no participants of the 1948 roundtable took a particular interest in Goldschmidt's review. To be sure, the discussants perceived that they and Goldschmidt belonged to the same school of genetics, which Lysenkoists identified as their opponent. Furthermore, they recognized fundamental errors made by Lysenko. Tanaka, for example, stated that Lysenko made 'a significant contribution in terms of a technique', but the phenomenon of vernalization was 'purely physiological', not 'genetic' (Iden, 1948: 17-18). However, their preference was not to dwell on criticisms of Lysenko but to explore the possibilities of developmental and physiological genetics. 
Several discussants suggested that developmental and physiological genetics could be explored in the effort to undertake more complex studies of the process of gene expression and that such studies would develop genetics in a new direction. Their comments reflected a long-standing interest in physiological genetics in Japan, an interest that was present well before the war (Iida, 2010, 2015). Japanese geneticists strongly believed that the future of genetics lay in what they referred to as a 'dynamic' rather than a 'static' approach. They took inspiration from Goldschmidt's (1938) book, Physiological Genetics, which had been published in 1938. They believed that Goldschmidt correctly identified the proper direction that genetics should take, namely, toward a study of how genes functioned in the cell and the organism. The more 'static' approach was, in the views of both Goldschmidt and Japanese biologists, too limiting biologically because it focused on mapping genes on chromosomes.

Postwar discussions of Lysenko's theory offered Japanese geneticists an opportunity to continue their discussion of physiological genetics as a future direction of genetics. During the war, physiological genetics was regarded as a way for Japanese scientists to lead the development of genetics, a field that had typically been represented by Western scholars. After Goldschmidt closely identified 'static' genetics with the mainstream genetics that had been developed in Morgan's laboratory in the United States, this association likely encouraged some Japanese geneticists to view its opposing school, 'dynamic' genetics, as an effective strategy to take leadership in the field of genetics (for a similar case in France, see Sapp, 1987: 123-162). This hope appeared attainable because the Japanese had been producing good work in the area corresponding to 'dynamic' genetics (Iida, 2015). In early 1948, when the country began to recover from its long isolation under the US occupation, many geneticists still hoped to develop genetics in the 'dynamic' direction and perceived Lysenko's theory as an effort similar to the Japanese one, namely, an effort to compete against the mainstream approach in a field dominated by Western scientists.

In 1945, immediately after the war, Yoshito Shinotō (1895-1989), a plant geneticist and professor at Tokyo University, published a book and promoted physiological genetics, which he called 'new genetics'. During the roundtable discussion in 1948 discussed above, he said that regardless of the quality of Lysenko's theory ('whether scientific or not'), Japanese geneticists should not be indifferent to the theory because the future direction of genetics must integrate environmental roles. He succinctly claimed at the meeting, 'We could say [Lysenko's biology] is one of the Soviet ways of pursuing physiological genetics' (Iden, 1948: 19). The popularity of Lysenko among younger researchers was also understood in terms of physiological genetics. During the meeting, Tanaka speculated that those younger researchers were also dissatisfied with a simple genetic theory (i.e. Mendelism) and that they might perceive 'something progressive' in Lysenko's theory, while another scientist commented that those who supported Lysenko's theory might be unaware of work in developmental and physiological genetics, and thus what they truly meant by a 'new genetics' could be physiological genetics (Iden, 1948: 18). While agreeing that Lysenko's theory did not appear sufficiently scientific, the overall discussion concluded that the current mainstream genetics had limitations; thus, physiological genetics should be advanced. 
For the Neo-Mendel group, what was most important was the actual practice of their idea of democracy, including discussions and experiments to examine the theory independently. Kōsuke Yamashita (1909-1988), a younger plant geneticist and a central figure in the formation of the group, was generally skeptical of Lysenko's claims but wanted to avoid using Goldschmidt's criticisms to denounce them. Instead, he suggested that geneticists should hold more discussions with those who actively introduced Lysenko's ideas and should conduct experiments to test Lysenko's claims. Independent discussions and scientific experiments conducted by geneticists in Japan were considered critical in a new society that was seeking to be democratic.

To present a broader picture of Lysenko's theory, members of the Neo-Mendel group edited a book of collected essays on Lysenko's theory that represented both 'sides' of this issue. The first edition of Lysenko Theory was published in 1948, and the Neo-Mendel group called it the 'definitive book' on explanations of Lysenko's theory (Neo-menderu-kai, 1948). The group attempted to include all key players: two established 'orthodox' geneticists (Yoshimaro Tanaka and Taku Komai), three Minka members who actively introduced the theory (including reprints of Yasugi's writings), two members of the Neo-Mendel group, and one agronomist who was the director of the National Agricultural Station. Yasugi's writings occupied more than a third of the entire book.

In an essay included in the book, Taku Komai (1886-1972), who had worked at Morgan's lab in 1923-1925 and established the first fly lab in Japan after his return, stated, 'Lysenko is not a scientist and his theory is not qualified as a scientific theory' (Komai, 1948: 189). This might appear to be a typical criticism, but it was an exception in the book. Indeed, there was no real debate between the 'two sides' in the book. This was likely the intention of the Neo-Mendel group; they wrote in the foreword that they hoped to see 'earnest criticisms' and 'reexamination of Lysenko's theory by follow-up experiments and applications' as soon as possible (Neo-menderu-kai, 1948: 2). Jūhei Satō (1911-1996), another younger plant geneticist and a central member of the group, evaluated highly The New Genetics in the Soviet Union, published in 1946 by P.S. Hudson and R.H. Richens at the Imperial Bureau of Plant Breeding and Genetics in England. This book addressed Lysenko's ideas, according to Sato (1948), 'at a purely academic level' without 'emotional criticisms' (pp. 7-8). Hudson and Richens suggested in 1946 that with 'co-operative research', much misunderstanding between the two schools would be removed, and 'geneticists of each school will be encouraged to examine their own and each others data in an unprejudiced light' (Hudson and Richens, 1946: 75). The contributors to the Japanese volume (except Komai) generally shared this accommodating attitude. In contrast to Komai, Tanaka made it clear that being an 'amateur' or lacking sufficient scientific background should not be a reason to reject a person's theory (Tanaka, 1948: 155). Although he criticized Lysenko's results, experiments, and presentation of his theory, Tanaka again suggested further steps that geneticists could take, such as the pursuit of physiological genetics and the replication of Lysenko's experiments. This general attitude among Japanese researchers did not change immediately after the news of the meeting of the Lenin All-Union Academy of Agricultural Sciences of the USSR, held from 31 July to 7 August 1948. 


\section{Continued after the 1948 purge}

At the Lenin All-Union Academy of Agricultural Sciences meeting of 1948, Lysenko denounced mainstream genetics, or what he termed 'Mendelist-Morganist theory', and declared that 'Soviet biologists hold that the Michurin principles are the only scientific principles' and that Mendelist-Morganists 'who deny the heritability of acquired characters are not worth dwelling on at too great length' (Lysenko, 1949: 49). During the Academy meeting, scholars who had supported Mendelist-Morganist genetics announced their conversion to Lysenkoist theory. The meeting and subsequent reports of such things as the forced closure of biological research institutes were perceived in the West as 'the complete defeat of neo-Mendelism and the enthronement of Michurinism as official doctrine in the sphere of genetics and evolution' (Huxley, 1949: 35).

Several leading geneticists in the United States immediately reacted and expressed deep concerns regarding the politics and denunciations of genetic science. Goldschmidt delivered an address in December at a meeting of the Phi Sigma Society and called Lysenko a 'fundamentalist' and a 'clever lawyer, almost a shyster' (Goldschmidt, 1949: 223). He warned that the Lysenko affair was no longer a local one. After mentioning that Lysenko's theory was incorporated into the high school curriculum in the Eastern Zone of Germany, he said,

We know that the red-tainted Japanese youth is already flirting with Lysenkoism and that a large scale discussion of it is going on in the Japanese press. Thus, the freedom of science is in danger everywhere, and the local affair becomes one of universal concern. (Goldschmidt, 1949: 226)

In contrast, there was no sign that Japanese geneticists regarded the existence of discussions of Lysenko's theory in their own country as a threat to their scientific freedom. In October 1948, during the 20th annual meeting of the Genetics Society of Japan, the NeoMendel group held a meeting, 'Heredity and Environment', with 70 participants and 14 discussants (Neo-menderu-kai, 1949). Satō opened the discussion by mentioning the Mendelists' forced conversion at the Academy meeting. Interestingly, however, the majority of the discussion that followed his opening remarks focused on problems of Mendelism, not of Soviet politics. Nobuhide Suita, a younger plant geneticist who was trained in Shinotō's laboratory, said, 'The mistake of Lysenko's theory is the very fact that he generalized [from one idea]', but there were some good observations that should be considered. He noted that Mendel succeeded because he selected characteristics that followed the Mendelian pattern. This was a success but simultaneously led in a 'wrong direction' wherein the role of the environment was 'unjustly ignored'. He also said that both Lysenkoists and anti-Lysenkoists were political, and the severe denunciations made by American geneticists seemed to him 'even more political' (Neo-menderu-kai, 1949: 46). Lacking detailed information on the Soviet situation and being under the US occupation, Japanese geneticists were generally skeptical of information from the American side.

Hideo Kikkawa (1908-1990), a prominent fly and silkworm geneticist who was trained under Komai, published a book, Iden (Heredity), in November 1948. In the book, he wrote that the series of events surrounding Lysenko's genetic theory was the saddest case in the history of science, in which ideological intrusion distorted science (Kikkawa, 
1948: 144). Kikkawa (1948) wrote that the cause was not to be found either in Lysenko's individual power or in the fault of Mendelian geneticists but rather in 'a confrontation of ideologies hanging low in the present world' (p. 151). He suggested that scientists 'shift away from these ideological positions and evaluate Lysenko's theory as pure science' and consider 'whether the theory is really worthless as Goldschmidt says'. The argument was that the clash of Soviet and American power clouded important problems in genetics. Kikkawa concluded that Lysenko had merely made a mistake in the 'expression of his ideas and use of examples' (Kikkawa, 1948: 154). Lysenko's idea had no fundamental difference from that of Mendelist-Morganists because both sides should agree that 'outer conditions could change the expression process of genetic characters and in some cases might cause a certain change in genetic materials themselves' (Kikkawa, 1948: 151-152). 'If we interpret [the theory] in this way', he wrote, 'we could say that it is a mistake to call the Mendel-Morgan theory wrong, but also it is an extreme that the Mendelist-Morganists do not find any suggestions or implications in Lysenko's theory' (Kikkawa, 1948: 154).

According to Kikkawa, a truly 'new genetics' would appear when both 'something close to Lysenko's ideas' and the 'chromosome theory' were integrated into one theory (Kikkawa, 1948: 154). To realize the 'new genetics', geneticists should develop physiological and biochemical genetics. Thus, the news of the notorious 1948 meeting made Japanese geneticists aware of the political intrusion into science but did not change the general tone of their reactions.

\section{Why were Japanese reactions sympathetic?}

Japanese discussions of Lysenko's ideas in the immediate postwar years reveal how the participants explored ways to reconstruct science and society under the US occupation. Participants in the discussion employed certain aspects of the ideas as a cultural resource to advance their own goals. There was no major conflict in opinions; younger and older generations of geneticists, as well as Marxists and non-Marxists, all explored the potential of Lysenkoism to advance their own goals. This situation was conditioned, to some extent, by the limited amount of information available in Japan. Although the Japanese were aware of the politicization of Lysenko, their isolation prevented the robust knowledge of it available in the United States. In addition, the type of information available in Japan was different. None of the Japanese biologists had intimate experience with Lysenkoism, unlike members of the US community (e.g. the geneticist Hermann J. Muller). Furthermore, the available sources ranged widely in their interpretations of Lysenko's theory, from Goldschmidt's negative review to Yasugi's 'rational interpretation' of Lysenko's ideas. However, the quantity and quality of information alone are insufficient to explain the pattern of the Lysenko discussion in Japan, especially to explain why biologists in Japan who had no interest in Marxist biology discussed Lysenko's theory in a sympathetic manner.

First, Japanese geneticists' scientific interests played a role in shaping their reactions toward Lysenko's theory. As Nakamura (1997 [1967]) suggested, the Japanese reactions to the theory and their interest in the roles of cytoplasm and the environment appear related (p. 119). In particular, the inheritance of acquired characters caused very different 
reactions among Japanese and American geneticists. The concept was perceived as the greatest 'mistake' in Lysenko's theory for many geneticists in the United States, but was not considered a fundamental misconception among the Japanese. There was no reason to strongly oppose the inheritance of acquired characters. The process of gene expression was unknown, and there was room for the notion that environmental factors in the cytoplasm caused a change in hereditary materials. In fact, there was some experimental evidence indicating that possibility. In the early 1940s in the United States, Tracy M. Sonneborn (1905-1981) proposed the existence of 'plasmagenes' (genes in the cytoplasm) in addition to nuclear genes, and his experimental evidence in Paramecium indicated possibilities for the inheritance of acquired characteristics through plasmagenes. Similarly, in yeast researchers found that certain environmentally induced adaptive changes were inherited. In 1946, in France, Boris Ephrussi (1901-1979) began experiments on cytoplasmic inheritance using yeast and soon became one of the leading spokespersons of adaptive mutations.

Although the Japanese were likely unaware of most of the above developments in cytoplasmic inheritance at this point, the foreign cases demonstrate that the Japanese were not exceptions in seeing that the inheritance of acquired characteristics was possible. In contrast, as Jan Sapp (1987) has shown, American 'nucleocentric' geneticists were strongly opposed to both cytoplasmic inheritance and the notion of the inheritance of acquired characteristics. This difference in the understanding of inheritance of acquired characteristics would explain why many American geneticists were able easily to dismiss the scientific issues that were suggestive to the Japanese in Lysenko's theory.

Importantly, for the Japanese, the aims of Goldschmidt's physiological genetics and Lysenko's ideas appeared similar because both theories sought to study the processes beyond the gene. Indeed, Lysenko had also advocated a physiological conception of heredity, and his vernalization and a technique developed by Goldschmidt were similar (see Sapp, 1987: 164, 168). Moreover, the dichotomy of 'static' versus 'dynamic' genetics advanced by Goldschmidt was applicable to Lysenko's theory, which was precisely situated in opposition to Mendelist-Morganists and to what Goldschmidt meant by 'static' genetics. One of the reasons why Japanese leftists were attracted to Lysenko's theory was that the theory was not a mere copy of an internationally dominant science. For geneticists, 'dynamic' genetics was regarded as a means of competing against American 'static' genetics. Therefore, defending physiological genetics and defending Lysenko's theory interestingly converged because both served the aim of competing against, superseding or simply 'not copying' American or Western science, which dominated the field of genetics. The similarities observed in the Japanese perspective are ironic, for Goldschmidt himself vehemently opposed Lysenkoism as equivalent to religious fundamentalism.

Therefore, by participating in the discussion of Lysenko's ideas, Japanese geneticists were able to restart their own discussion regarding the future direction of genetic research in Japan. Furthermore, by emphasizing the 'shared' goal between Lysenko's ideas and physiological genetics, it was possible for established geneticists of the older generation to communicate with younger geneticists during this volatile period. The Neo-Mendel group's members were socially active and, for example, voiced their critical opinions regarding the establishment of a new research institute proposed by older geneticists. ${ }^{1}$ 
Thus, good communication within the discipline of genetics was vital for its swift reconstruction.

For younger researchers, older geneticists' treatment of the Lysenko matter potentially represented a sort of test that could indicate how democratic the discipline could be. Thus, most geneticists of the older generation hoped to meet their younger colleagues' expectations in the new era and chose to express their opinions very carefully to avoid creating the appearance of establishing 'orthodoxy'. Younger scientists in Japan perceived that one important way to practice new democracy was to promote discussions. The Neo-Mendel group organized public discussions and edited and published various opinions on Lysenko's ideas. Through these activities, the group shaped the overall discussions to fit their image of democratic discussions, that is, to be as non-dogmatic as possible. In this atmosphere, denunciation of certain opinions was likely regarded as opposition to the social current of broad reform. If geneticists of the older generation were to communicate with younger researchers, simple denunciations were not merely ineffective but harmful. Thus, these discussions almost completely avoided political matters and focused on the suggestive topics in Lysenko's theory, including the commonality between physiological genetics and Lysenko's theory, which allowed all participants to engage with the discussions in a rather positive manner.

Geneticists' concerns regarding the reconstruction of their field also significantly overlapped with those of leftists, including democratizing scientific practice, finding a unique direction for research, and contributing directly to the reconstruction of society. In particular, there was an acute perception that contributing to the reconstruction of the nation was intellectuals' moral obligation. Although Japanese genetics had significantly contributed to the agricultural industry, the severe food scarcity in the postwar years facilitated further self-criticisms of the genetics of the past. Such shared sentiments among many intellectuals in the wake of the defeat also shaped the discussion of Lysenko's ideas to be sympathetic and without dispute.

Finally, there was no strong political reason for the Japanese to denounce Lysenkoism. Lysenko and Stalin divided the world of geneticists into those of the West and those of the Soviet Union. Although the United States was then attempting to make Japan its political ally, most geneticists in Japan did not identify with the West and thus did not strongly feel 'attacked' by Lysenkoists. Moreover, Japanese intellectuals overall were rather left-leaning and did not have strong anti-communist sentiments at this time. They were generally skeptical of Lysenko-related information originating in American sources. Thus, Japanese geneticists had scientific and political interest in continuing sympathetic discussions, and there was less incentive for them to sharply criticize Lysenko's ideas.

\section{Genetics of a liberal-democratic state: the emergence of a controversy}

As the anti-communism campaign began in Japan, Lysenko's ideas were increasingly identified with communism, and criticizing the ideas came to be regarded as combating communism. Sympathetic discussions of Lysenko's ideas waned. As Japan began to reconnect with other countries, geneticists' reactions were increasingly aligned with 'international' or American values. The Lysenko issue was no longer addressed through 
democratic discussions that carefully avoided establishing orthodoxy. Instead, criticisms resembling those expressed by many American geneticists began to appear in Japan. With the shift in the political context, Japanese geneticists' use of Lysenko's idea as a cultural resource also shifted, being used to gain authority and recognition internationally and to continue the effective reconstruction of their discipline.

In 1948, US Secretary of the Army Kenneth C. Royall announced major modifications to occupation policies in Japan by claiming that 'the real well-being' or democracy of Japan was secondary to the US fight against communism (quoted in Matsuda, 2007: 44). After the October 1949 establishment of the People's Republic of China, the task of maintaining Japan as a US ally became even more critical for American officials. SCAP, which initially sought the democratization and demilitarization of Japan, shifted its primary goal to combating communism in Japan. Critics in Japan called the shift in SCAP's political direction the 'reverse course'. This clear reversal included the militarization of Japan by establishing the National Police Reserve (1950) and the change in the targets of purges from conservatives to leftists. Nearly two-thirds of those who had been purged after the war were allowed to return to work (see Matsuda, 2008: 63-64), but the Red Purge began in Japan. According to Hiroshige (1960), the first sign of the Red Purge against scientists appeared in July 1949, when a SCAP officer lectured at one university that a Communist Party member was inappropriate as a faculty member (p. 67).

In June 1950, SCAP made the Japanese Communist Party illegal. After 3 weeks, the Korean War began. Because top members of Minka included Communists, by 1950 SCAP came to regard it as one of the 'known Communist fronts'. ${ }^{2}$ Minka membership (both past and present) became a cause for the rejection of applications for US visas (Tsuge, 1980: 172). Hajime Matsuura, a cytologist and the president of the Minka Biological Division, was denied permission by SCAP to go abroad in 1950 for an international conference of botanists (Hiroshige, 1960: 68). Many Minka members who did not wish to be associated with communism and did not wish to lose the substantial opportunity of conducting research in the United States left the Association and even requested that the record of their membership be erased. Consequently, the membership of more than 10,000 in 1950 declined to approximately 5000 within one year (Tsuge, 1980: 172, 179). In response to this pressure, however, leftist students resisted. The more communism was repressed in Japan, the more Lysenko's theory gained popularity among 'progressive students'.

Against this political background, adopting an anti-Lysenkoist stance became important for geneticists, to protect and develop both their careers and the discipline of genetics. Through their interactions with American scholars and officials, Japanese geneticists had learned that established geneticists were expected to 'combat' Lysenkoism. Such criticisms were particularly important for those interested in cytoplasmic inheritance and the inheritance of acquired characteristics because these topics could very easily be regarded as 'Lysenkoist', often with the implication of 'communist' (see Krige, 2008: 115-151; Sapp, 1987: 163-191). Japanese geneticists had once openly discussed the 'similarities' between Lysenko's ideas and their interests (physiological genetics), but this became risky. In 1950, the prominent plant geneticist Hitoshi Kihara (1893-1986), who had been director of an important genetic research laboratory in Japan since the 1920 s and who had interests in 'non-Mendelian' topics, published full-length articles criticizing Lysenko's theories and politics for the first time and made a statement in the 
newspaper announcing that he was an anti-Lysenkoist (Kihara, 1950b, 1950c, 1950d). He also lectured, in the same year, against the careless use of the word 'Lysenkoist' by Japanese scientists. For example, some bacteriologists in Japan, as Kihara noted, claimed to be 'Lysenkoists' when they only meant that they studied adaptive mutations or the inheritance of acquired characteristics. Kihara warned that scholars should understand Lysenko's claims well and noted that '[w]e must mind our language' (Kihara, 1950a: 9). As with other geneticists who worked on 'non-Mendelian' topics, such as Sonneborn, Kihara clearly aligned his interests with the Mendel-Morgan school to demarcate his science from Lysenkoism (Iida, 2010).

Many American geneticists and officials regarded Lysenko's theory as the antithesis of science and a threat to democracy (e.g. Muller, 1949: 106). Following this interpretation was crucial because scientists' behavior concerning Lysenkoism could affect important aspects of their professional life, such as publications and funding. In the early 1950s, many intellectuals, including officers of the Rockefeller Foundation, were influenced by the popular conception that science was possible only in a liberal-democratic state, not in a totalitarian state. This notion was originally developed to criticize the Nazis by anti-fascist intellectuals, including Robert K. Merton (Hollinger, 1983). Under the pressure of the 1950 McCarran Act, Rockefeller Foundation officers used their idea of what science should be to reject support for communist or left-wing scientists (Krige, 2008: 146-149). This particular conception of science also affected scientists who worked outside the United States, through American individuals who served as officers at funding agencies, journal editors, collaborators, and coauthors.

In 1952, for example, Kihara (1982 [1952]) published a review of Lysenko's work in English in an Indian journal Science and Culture because he felt that it was his 'duty to offer [his] opinion' on Lysenko's ideas. The article was critical of Lysenko's work, but his critique was apparently not sharp enough for American geneticists. Kihara concluded the review by noting his hope that in the near future, the true value of genetics would be recognized in the Soviet Union, and genetic research would be conducted again for the nation and the people. According to Kihara (1971: 46), this passage was criticized as being 'a little too optimistic'. In the following year, Kihara and the American cytogeneticist Karl Sax published an edited version of Kihara's review in Journal of Heredity (Kihara and Sax, 1953). The editing included the elimination of the 'optimistic' sentence and significant rewriting to make it clear that Lysenko's idea was not science (e.g. Lysenko was 'moronic' instead of 'unlearned', and his idea was taken seriously 'by fiction writers who invaded the field of science' instead of 'even in the scientific world').

The appearance of anti-Lysenkoism in Japan was further facilitated by broader US cultural diplomacy intended to combat communism. As the historian Takeshi Matsuda (2008) argues, American officials planning to end the occupation detailed a plan to facilitate cultural exchange between the two countries, such as the establishment of cultural centers and exchange programs for students and scholars (pp. 155-188). Through the cultural exchange offered by the United States, Japanese intellectuals continued to be reconnected with the outside world after the end of the occupation. As intended by American cultural diplomacy, Japanese intellectuals were able to efficiently reconstruct their fields with American help, and they generally became quite sympathetic to American political ideals. 
In addition, influential Japanese intellectuals were invited to join the Congress for Cultural Freedom, the organization created by the US Central Intelligence Agency in 1950 to influence the opinions of intellectuals in order to maintain an anti-communist consensus on an international scale (e.g. Saunders, 1999; Scott-Smith, 2002; Wilford, 2008). Although it chiefly targeted European intellectuals, helping to foster the sense that the United States and Western Europe shared and needed to defend a common cultural heritage, the Congress planned to establish a Japanese branch, which was later named the Japanese Committee for Cultural Freedom. By March 1951, a working group of Japanese and Americans developed a tentative list of Japanese members, including two geneticists (Kihara and Komai). Core members of the American Committee were confident that Japanese intellectuals would willingly join the Committee. They explained that 'the sense of being accepted internationally, the sense of being part of an international movement, have a profound psychological meaning to the Japanese, who have been cut off from the outside for so long'. ${ }^{3}$ An invitation to be a member of the Congress was expected to be irresistible for Japanese intellectuals who longed for connections with Western intellectuals. Because the Congress was successfully normalizing the values of the American-dominated West (Scott-Smith, 2002), Japanese scientists were better off joining the dominant international scientific community in order to have their science regarded as 'proper' science.

Hermann J. Muller (1890-1967), who received the Nobel Prize in 1946, was known in Japan as one of the 'severest critics' of Lysenko (Asahi Shimbun, 1951). Muller attended the Congress of Cultural Freedom held in India in 1951 and stopped in Japan on his return to the United States to deliver anti-Lysenko lectures in several locations (Yomiuri Shimbun, 1951). This plan was developed by the American Committee, which strongly recommended that Muller make the stop because he was considered 'enormously effective among intellectuals and university people' in Japan. ${ }^{4}$ SCAP must have enthusiastically supported Muller's visit. SCAP reported in January 1951 that most 'Communists and pro-Communists among the new membership of the JSC [Japan Science Council]' were university professors and were concentrated in 'the Kyoto-Osaka and the Nagoya areas'. ${ }^{5}$ The report continued, 'The universities in these areas are strongholds of the Democratic Scientists Association [Minka]'. One of Muller's anti-Lysenko lectures was delivered at Kyoto University, where the 'student body was among the most radical in Japan' (Schull, 1990: 103).

Mitoshi Tokuda (1906-1975), who was a pro-Lysenkoist and a former student of Komai, attended the talk and later commented that he 'did not have any impression that Lysenko's theory was defeated completely’ (Tokuda, 1952: 9-10). In 1952, Tokuda published a pro-Lysenko book, Two Genetics. A developmental biologist, Tokindo Okada (b. 1927), recalled that the book essentially became the 'Bible' for leftist students when he was a graduate student at Kyoto University in the early 1950s (Okada, 2007: 68). In Two Genetics, Tokuda (1952) insisted that a compromise between 'Lysenkoists' and 'MendelistMorganists', which had been discussed as a possibility by many participants in previous discussions of Lysenko's theory in Japan, was unacceptable.

It was not only Tokuda who adopted an uncompromising position. As Nakamura noted, individuals who favored Lysenko's theory but who had previously shown flexible attitudes toward the theory began faithfully to adhere to it. For them, defending Lysenko's 
theory came to be regarded as the defense of their political views. Whether one supported Lysenko's theory functioned as a test of one's commitment to remain a member of the Communist Party and defend his or her ideological position (Tomari, 2008: 123). As anti-communism campaigns became louder, supporters of Lysenko's ideas grew more dogmatic. Meanwhile, discussions of Lysenko's ideas (such as roundtable discussions hosted by younger geneticists) declined. Yasugi, who had introduced Lysenko's theory for idealistic reasons and who was not a communist, deplored how discussions of Lysenko's ideas had evolved in Japan. He stated in 1956 that Lysenko himself should go back to 'the basis of his original theory - interactions between the environment and organisms' (Seibutsu-kagaku, 1956: 165).

Denunciations by geneticists began to appear more frequently in Japan. In 1954, Kikkawa, who had in 1948 suggested an integration of Mendelism and certain aspects of Lysenko's theory, criticized Lysenko supporters such as Tokuda who approached farmers to spread Michurin methods; indeed, Kikkawa (1954) equated the pro-Lysenkoists to 'quacks' dealing with patients (p. 91). In the same year, the geneticist who had facilitated the 1948 roundtable discussion of Lysenko's theory wrote an article entitled 'Lysenko's pseudoscience' in the magazine Iden and described Lysenko's theory as a 'delusion theory' and Lysenkoism as 'fanaticism of the ignorant' (Takenaka, 1954: 9). Komai concluded that Lysenko was akin to the founder of a cult and asked believers in Japan to reconsider their blind faith (Komai, 1954: 7). In 1948, he had been an exception in denouncing Lysenko and his ideas, but he was no longer an exception after 1950.

\section{A controversial idea and scientists' tactics}

There were several reasons for the appearance of sharper criticisms. Whereas many continued to have research interests in the inheritance of acquired characters and adaptive mutations, the simple dichotomy of 'dynamic' and 'static' genetics became outdated as new lines of research developed. Thus, advancing their theoretical preference based on this dichotomy became scientifically less relevant, which made it unnecessary to mobilize Lysenko's ideas to support their argument. In addition, the ramifications of the 1948 Lenin All-Union Academy of Agricultural Sciences meeting cannot be discounted; some of the older geneticists personally knew Russian colleagues who fell victim to the Soviet political struggle, including Vavilov - who had visited Japan in 1929 - and felt deep sympathy for them. While empathy with Soviet colleagues and the development of genetics to embrace a more complex framework help explain the shift of Japanese scientists' reactions to Lysenko, my argument, made throughout this article, is that these reasons explain only part of the story.

Ironically, the anti-communism movement launched to ostensibly defend liberaldemocratic values substantially damaged democratic movements. As Jessica Wang (2002) describes, the American atomic scientists' movement collapsed under Cold War surveillance. In Japan, too, the scientists' movement waned because of purges and censorship. Minka also became defunct by 1957. Expectations for creating a new democratic society began to crumble and were replaced by the 'acceptance of authority' or a 'sense that ordinary people were really unable to influence the course of events' (Dower, 1999: 439-440). 
Similarly, Japanese discussions of Lysenko's ideas that were closely related to the postwar democratization movement were significantly affected. As the Cold War progressed, the primary meaning of 'democracy' for scientists shifted from a fundamental process to a code for 'science' that was defined by the values of a liberal-democratic state. Japanese geneticists felt pressure to demonstrate that they were confronting Lysenko's position. Their primary audience in this respect shifted from domestic intellectuals to the international community, particularly Americans. To demonstrate that their science was democratic and thus properly scientific, lengthy discussions were no longer required; instead, it was more important to attack an element that threatened this democratic science. Because their scientific understanding of Lysenko's theory did not change substantially, they shifted the focus of their attention from its implications (the role of the environment) to the clearly inaccurate claims regarding known genetic findings. For Japanese geneticists, sharper criticisms became a way to be recognized as world-class geneticists and to obtain membership in the international circle that was bonded by an anti-communism and an anti-totalitarian spirit. This was critical for the effective reconstruction and further development of their discipline.

Whether an idea can be regarded and addressed as 'controversial' depends not only on the content of the idea but also on the context. Based on the context, scientists can determine the status of potentially controversial ideas, choose aspects on which to focus and select appropriate actions in response. Scientists' tactics might not only steer and resolve controversies but also create or suppress them. Thus, we can see a controversial idea with publicity as a substantial cultural resource that scientists can use in multiple ways, directed toward a range of goals.

\section{Acknowledgements}

I would like to thank Sharon Kingsland for suggestions and encouragement on many earlier drafts, the anonymous reviewers for this journal, Susan Lindee, Sergio Sismondo, Koichi Mikami, and Kenji Ito for helpful comments at a later stage, and Mark Vardy for improving my English on the final draft. I also thank William deJong-Lambert and Nikolai Krementsov for offering me the opportunity to present an earlier version of this paper at The Second International Workshop on Lysenkoism in Vienna in 2012 and for their discussions. Finally, I am grateful to Yuriko Kihara, a daughter of Hitoshi Kihara, who allowed me to read his paper collections, and to Teiri Nakamura who kindly shared his recollections around the time of the controversy.

\section{Funding}

This work was partly supported by JSPS KAKENHI (grant numbers 22800020, 24700922).

\section{Notes}

1. 'Kokuritsu idengaku kenkyūjo setsuritsu ni kansuru "neo-menderu-kai" no kōdō ni taisuru Sapporo danwakai no kaitō' [Opinions of the Sapporo branch meeting on the actions taken by the Neo-Mendel group, regarding the establishment of the national institute of genetic research], 1948 or 1949, file 'hozon shihen 1952-', owned by Ms Yuriko Kihara, Yokohama, Japan.

2. 'Summary of Information: Communist Influences in the Japan Science Council (JSC)', 26 January 1951, folder 'JSC Political', box 7433, RG331, National Archives, College Park, Maryland, USA. 
3. Untitled, 5 March 1951, folder 25, box 7, TAM023, Tamiment Library, New York University, New York, NY, USA. See p. 3.

4. Untitled, 5 March 1951, p. 3.

5. 'Summary of Information: Communist Influences in the Japan Science Council (JSC)'.

\section{References}

Asahi Shimbun (1951) Futatsu no idengakusetsu [Two theories of genetics], p. 2, 20 March.

Bernal JD (1939) The Social Function of Science. London: George Routledge \& Sons.

Cassata F (2012) The Italian communist party and the 'Lysenko affair' (1948-1955). Journal of the History of Biology 45: 469-498.

DeJong-Lambert W (2009) From eugenics to Lysenkoism: The evolution of Stanisław Skowron. Historical Studies in the Natural Sciences 39(3): 269-299.

DeJong-Lambert W (2012) Lysenkoism in Poland. Journal of the History of Biology 45: 499-524.

DeJong-Lambert W and Krementsov N (2012) On labels and issues: The Lysenko controversy and the Cold War. Journal of the History of Biology 45: 373-388.

Dower JW (1999) Embracing Defeat: Japan in the Wake of World War II. New York: W.W. Norton \& Company.

Dunn LC (1946) Heredity and its variability by T. D. Lysenko (review). Science 103(2667): 180-181.

Glass B (1946) Heredity and its variability by T. D. Lysenko (review). Quarterly Review of Biology 21(3): 279.

Goldschmidt R (1938) Physiological Genetics. New York: McGraw-Hill Book Company.

Goldschmidt R (1946) Review: Heredity and its variability, by T. D. Lysenko translated by Dobzhansky. Physiological Zoology 19(3): 332-334.

Goldschmidt R (1949) Research and politics. Science 109(2827): 219-227.

Gordin MD (2012) How Lysenkoism became pseudoscience: Dobzhansky to Velikovsky. Journal of the History of Biology 45: 443-468.

Graham LR (1987) Science, Philosophy, and Human Behavior in the Soviet Union. New York: Columbia University Press.

Harman OS (2003) C.D. Darlington and the British and American reaction to Lysenko and the Soviet conception of science. Journal of the History of Biology 36: 309-352.

Hiroshige T (1960) Sengo nihon no kagaku undō [The Science Movement in Postwar Japan]. Tokyo, Japan: Chūōkōronsha.

Hollinger DA (1983) The defense of democracy and Robert K. Merton's formulation of the scientific ethos. Knowledge and Society 4: 1-15.

Hudson PS and Richens RH (1946) The New Genetics in the Soviet Union. Cambridge: Imperial Bureau of Plant Breeding and Genetics.

Huxley J (1949) Heredity, East and West: Lysenko and World Science. New York: Henry Schuman.

Iden (1948) Atarashii idengaku hihan (zadankai) [Criticisms of new genetics (roundtable discussion)]. Iden 2: 14-20.

Iida K (2010) Practice and politics in Japanese science: Hitoshi Kihara and the formation of a genetics discipline. Journal of the History of Biology 43: 529-570.

Iida K (2015) Genetics and 'breeding as a science': Kihara Hitoshi and the development of genetics in Japan in the first half of the twentieth century. In: Phillips D and Kingsland S (eds) New Perspectives on the History of Life Sciences and Agriculture. New York: Springer, 439-458.

Joravsky D (1970) The Lysenko Affair. Cambridge, MA: Harvard University Press.

Kihara H (1950a) Risenko gakusetsu no hinan [Criticisms on the Lysenko theory]. Iden 4(3): 2-9.

Kihara H (1950b) Risenko no idengaku to sono hankyō (I) [Lysenko's genetics and the responses (I)]. Shizen 5(2): 44-49.

Kihara H (1950c) Risenko no idengaku to sono hankyō (II) [Lysenko's genetics and the responses (II)]. Shizen 5(3): 60-72. 
Kihara H (1950d) Ruisenko ronsō: Hantai, Jikken hōhō ga fubi [Lysenko controversy: Objection, experimental methods are inadequate]. Asahi Shimbun, 2 March.

Kihara H (1982 [1952]) T.D. Lysenko Wheat Studies: Retrospects and Prospects. Tokyo, Japan; Amsterdam: Kodansha; Elsevier Scientific, pp. 211-214.

Kihara H (1971) Sonotoki wa kita: Jūnen mae ni nozonda koto [The time has come: What I hoped ten years ago]. Shizen 26(12): 44-48.

Kihara H and Sax K (1953) Genetics in the USSR. Journal of Heredity 44(4): 132, 158.

Kikkawa H (1948) Iden [Heredity], 2nd edn. Kyoto, Japan: Nihon kagakusha.

Kikkawa H (1954) Nihon no michūrin gakuha to sono nōhō ni tsuite [About the Michurin school in Japan and their agricultural method]. Seibutsu-kagaku 6(2): 90-91.

Komai T (1948) Ruisenko no idengaku hihan [Lysenko's criticism of genetics]. In: Neo-menderukai (ed.) Ruisenko gakusetsu [Lysenko Theory]. Tokyo, Japan: Hokuryūkan, 173-191.

Komai T (1954) Ruisenko no shikkyaku [The fall of Lysenko]. Iden 8(9): 4-7.

Krementsov N (1997) Stalinist Science. Princeton, NJ: Princeton University Press.

Krige J (2008) American Hegemony and the Postwar Reconstruction of Science in Europe. Cambridge, MA: The MIT Press.

Lysenko TD (1946) Heredity and Its Variability (trans. T Dobzhansky). New York: King's Crown Press.

Lysenko TD (1949) The Situation in Biological Science: Address Delivered by Academician T. D. Lysenko on the Situation in Biological Science; Proceedings of the Lenin Academy of Agricultural Sciences of the USSR, July 31-August 2, 1948, Verbatim Report. Moscow: Foreign Languages Publishing House.

McGucken W (1984) Scientists, Society, and State: The Social Relations of Science Movement in Great Britain 1931-1947. Columbus, OH: Ohio State University Press.

Martin B and Richards E (1995) Scientific knowledge, controversy, and public decision making. In: Jasanoff S, Markle GE, Petersen JC and Pinch T (eds) Handbook of Science and Technology Studies. Thousand Oaks, CA: SAGE, 506-526.

Matsuda T (2007) Soft Power and Its Perils: US Cultural Policy in Early Postwar Japan and Permanent Dependency. Stanford, CA: Stanford University Press.

Matsuda T (2008) Sengo nihon ni okeru amerika no sofuto pawā: Han-eikyūteki izon no kigen [American Soft Power in Postwar Japan: The Origin of Semi-Permanent Dependency]. Tokyo, Japan: Iwanami Shoten.

Morris-Suzuki T (1994) The Technological Transformation of Japan: From the Seventeenth to the Twenty-first Century. Cambridge: Cambridge University Press.

Muller HJ (1949) Genetics in the scheme of things. In: Bonnier G and Larsson R (eds) Proceedings of the Eighth International Congress of Genetics: 7th-14th of July, 1948. Lund: Berlingska Boktryckeriet, 96-127.

Nakamura T (1997 [1967]) Nihon no ruisenko ronsō [The Lysenko Controversy in Japan]. Tokyo, Japan: Misuzu Shobō.

Nakayama S (2001) The association of democratic scientists (Minka). In: Nakayama (ed) A Social History of Science and Technology in Contemporary Japan, vol. 1: The Occupation Period 1945-1952. Melbourne, VIC, Australia: Trans Pacific Press, 470-481.

Neo-menderu-kai (1948) Forward. In: Neo-menderu-kai (ed.) Ruisenko gakusetsu [Lysenko Theory]. Tokyo, Japan: Hokuryūkan.

Neo-menderu-kai (1949) Iden to kankyō (zadankai) [Heredity and environment (roundtable discussion)]. Iden 3(3): 43-48.

Oguma E (2002) 'Minshu' to 'aikoku': Sengo nihon no nashonarizumu to kōkyōsei [Democracy and patriotism: Postwar Japanese nationalism and the public sphere]. Tokyo, Japan: Shinyōsha. 
Ohara Institute for Social Research of Hosei University (OISRHU) (1965) Nihon rōdō nenkan (bekkan): Taiheiyō sensō ka no rōdō undō [The Labor Yearbook of Japan (special edition): Labor Movements during the Pacific War]. vol. 4, chap. 1-1. Available at: http://oohara. mt.tama.hosei.ac.jp/rn/senji2/rnsenji2-119.html (accessed 10 May 2014).

Okada T (2007) Ruisenko no jidaiga atta [Lysenko's era in the past]. In: Nakamura K (ed.) Seimei kenkyū no paionia tachi [Pioneers in Life Science]. Kyoto, Japan: Kagaku dōjin, pp. 63-75.

Onaga L (2015) More than metamorphosis: The silkworm experiments of Toyama Kametaro and his cultivation of genetic thought in Japan's sericultural practices, 1894-1918. In: Phillips D and Kingsland S (eds) New Perspectives on the History of Life Sciences and Agriculture. New York: Springer, 415-437.

Onuma M, Fujii Y and Kato K (1975) Sengo nihon kagakusha undōshi 1 [The History of the Postwar Scientists' Movement in Japan 1]. Tokyo, Japan: Aoki Shoten.

Paul DB (1983) A war on two fronts: J. B. S. Haldane and the response to Lysenkoism in Britain. Journal of the History of Biology 16(1): 1-37.

Roll-Hansen N (2005) The Lysenko Effect: The Politics of Science. Amherst, NY: Humanity Books.

Sakata S (1947) Kenkyū to soshiki [Research and organization]. Shizen 2(9): 10-13.

Sapp J (1987) Beyond the Gene: Cytoplasmic Inheritance and the Struggle for Authority in Genetics. Oxford: Oxford University Press.

Sato J (1948) Developments of the Lysenko controversy. In: Neo-menderu-kai (ed.) Ruisenko gakusetsu [Lysenko Theory]. Tokyo, Japan: Hokuryūkan, 1-14.

Saunders FS (1999) The Cultural Cold War: The CIA and the World of Arts and Letters. New York: New Press.

Schneider L (2003) Biology and Revolution in Twentieth Century China. Lanham, MD: Rowman \& Littlefield.

Schneider L (2012) Michurinist biology in the People's Republic of China, 1948-1956. Journal of the History of Biology 45: 525-556.

Schull WJ (1990) Song among the Ruins. Cambridge, MA: Harvard University Press.

Scott-Smith G (2002) The Politics of Apolitical Culture: The Congress for Cultural Freedom, the CIA and Post-War American Hegemony. London: Routledge.

Seibutsu-kagaku (1956) Zadankai: Ruisenko gakusetsu o megutte [Roundtable discussion about Lysenko's theory]. 8(4): 160-165.

Selya R (2012) Defending scientific freedom and democracy: The Genetics Society of America's response to Lysenko. Journal of the History of Biology 45: 415-442.

Sismondo S (2010) An Introduction to Science and Technology Studies, 2nd edn. Chichester, West Sussex: Wiley-Blackwell.

Takenaka Y (1954) Ruisenko no ese idengaku [Lysenko's pseudogenetics]. Iden 8(9): 8-12.

Taketani M (1969 [1946]) Gijutsu o warera no teni [Getting technology in our hands]. Reprinted in: Kagaku to gijutsu, Taketani Mitsuo chosakushū 4 [Science and Technology, Essays by Mitsuo Taketani 4]. Tokyo, Japan: Keisō Shobō, 113-121.

Tanaka Y (1948) Menderizumu to ruisenko gakusetsu [Mendelism and Lysenko's theory]. In: Neo-menderu-kai (ed.) Ruisenko gakusetsu [Lysenko Theory]. Tokyo, Japan: Hokuryūkan, $154-172$.

Tokuda M (1952) Futatsu no idengaku [Two Genetics]. Tokyo, Japan: Rironsha.

Tomari J (2008) Pureeto tekutonikusu no kyozetu to juyō: sengo nihon no chikyūkagakushi [Rejection and Reception of Plate Tectonics: History of Earth Science in Postwar Japan]. Tokyo, Japan: Tokyo Daigaku Shuppankai.

Tsuge H (1980) Minka to watakushi: Sengo ichi-kagakusha no ayumi [Minka and I: Autobiography of One Postwar Scientist]. Tokyo, Japan: Keisō Shobō. 
Wang J (2002) Scientists and the problem of the public in Cold War America, 1945-1960. Osiris (2nd ser) 17: 323-347.

Whyte RO (1948) History of research in vernalization. In: Murneek AE and Whyte RO (eds) Vernalization and Photoperiodism: A Symposium. Waltham, MA: Chronica Botanica.

Wilford H (2008) The Mighty Wurlitzer: How the CIA Played America. Cambridge, MA: Harvard University Press.

Wolfe A (2010) What does it mean to go public? The American response to Lysenkoism, reconsidered. Historical Studies in the Natural Sciences 40: 48-78.

Wolfe A (2012) The Cold War context of the golden jubilee, or, why we think of Mendel as the father of genetics. Journal of the History of Biology 45: 389-414.

Yamamoto K (1935) Yarovization ni tsuite [On vernalization]. Nogyo oyobi engei [Agriculture and Horticulture] 10(8): 1882-1892.

Yasugi R (1948) Ruisenko rongi ni tsuite [On the Lysenko discussion]. In: Neo-menderu-kai (ed.) Ruisenko gakusetsu [Lysenko theory]. Tokyo, Japan: Hokuryūkan, 21-40.

Yasugi R (1968) On the dispute of Lysenkoism. Journal of Japanese Scientists 3(1): 60-61 (in Japanese).

Yomiuri Shimbun (1951) Jiyū wa tatakaitore [Freedom, gain it by fighting for it], p. 2, 11 April. Morning. p. 2.

\section{Author biography}

Kaori lida is a lecturer at SOKENDAI (The Graduate University for Advanced Studies), Hayama, Japan. Her current research examines the history of Japanese genetics, mainly in the 1930s-60s. She has a $\mathrm{PhD}$ in genetics from Pennsylvania State University and $\mathrm{PhD}$ in history of science from Johns Hopkins University. 